\title{
出血発症もやもや病に対する直接血行再建術の効果 および長期的予後について
}

\author{
中川 一郎，川口正一郎，飯田 淳一，榊 寿右
}

\section{Direct Bypass of STA-MCA Anastomosis Prevents Future Stroke in Patients with the Hemorrhagic Type of Moyamoya Disease}

Ichiro Nakagawa, M.D., Shoichiro Kawaguchi, M.D., Junichi IIDA, M.D., and

Toshisuke SAKAKI, M.D.

Department of Neurosurgery, Nara Medical University, Kashihara, Japan

Summary: The prevention of future stroke is an important issue in hemorrhagic type moyamoya disease. However, the surgical treatment of moyamoya disease in adult hemorrhagic type is still controversial. We undertook the present study to analyze the effect of direct surgery of STA-MCA anastomosis on the prevention of future stroke in patients with the hemorrhagic type of moyamoya disease. We analyzed 30 patients with adult moyamoya disease whose mean age was 44 years old. The follow-up period was from 0.8 to 15.1 years after initial onset of intracerebral hemorrhage.

Direct bypass surgery was performed on 10 patients and recurrence of hemorrhage was observed in 1 patient (10\%) 9.3 years after first onset of hemorrhage. Indirect surgery was done on 6 patients, and 3 patients had future strokes (50\%). Of the remaining 14 patients treated conservatively, stroke recurred in 8 patients (57\%) during follow-up (average 2.71 years). The rate of future strokes and stroke-free time in the patients treated with direct bypass surgery was significantly lower $(\mathrm{P}<0.05)$ than that of patients managed conservatively or with indirect bypass surgery.

In conclusion, in case of adult hemorrhagic type of moyamoya disease, direct bypass of STA-MCA anastomosis effectively prevents rebleeding and ischemic events.
Key words:

- STA-MCA anastomosis

- intracranial hemorrhage

- moyamoya disease

Surg Cereb Stroke (Jpn) 32: 416-420, 2004

\section{はじめに}

もやもや病は脳主幹動脈の閉塞性疾患であり，二次的に 豊富な副血行路を認める原因不明の疾患である。 小児を中 心とする虚血発症のもやもや病に対する直接および間接血 行再建術の有用性は一般に認められているが1)2), 成人発 症例に多いとされる出血発作で発症したもやもや病は虚血 症例よりも予後不良であり，これらに対する手術適応，手
術手技についてはいまだ一定の見解が得られていない1)214) 9).今回われわれは出血発症したもやもや病に対して直接 血行再建術 (STA-MCA 吻合術) を施行し, 間接血行再建 術 (EDAS) 施行例, 保存的治療施行例と比較し, その長期 予後を既報告 ${ }^{6)}$ 以後に経験した症例とその後の経過につい てさらに検討を加え, 頭蓋内出血で発症したもやもや病の 治療方針を示した。

奈良県立医科大学 脳神経外科(受稿日 2004.6.15)〔連絡先： $\mathbf{T} 634-8522$ 奈良県橿原市四条町 840 奈良県立医科大学 脳神経外科 中 川一郎] [Mailing address: Ichiro NAKAGAWA, M.D., Department of Neurosurgery, Nara Medical University, 840 Shijo-cho, Kashihara, Nara 634-8522, Japan] 


\section{対象および方法}

奈良県立医科大学脑神経外科㧍よび関連施設にて経験し た頭蓋内出血で発症したもやもや病 30 例を対象とした. 年齢は 16-61 歳, 平均年齢 44歳, 男性 9 例, 女性 21 例で あった．診断は脳血管撮影にて行い，血管撮影上脳動脈瘤 が認められる症例は対象から除外した。頭部 CT 撮影によ る頭蓋内出血の夕イプは, 脳内出血のみを認めたもの 12 例, 脳内出血と脳室内出血の両方を認めたもの 8 例, 脳室 内出血のみ認めたもの 10 例であった，脳内出血に対する 初期治療としては血腫除去術を施行したもの5例, 脳室ド レナージのみ施行したもの 2 例，保存的加療を行ったもの 23 例であった。発症 3 カ月後の転帰は, Modified Rankin Disability Scale (MDS) そて score 0 (No symptoms at all)：15例, score 1 (No significant disability despite symptoms)：7例, score 2 (Slight disability)：5例, score 3 (Moderate disability)：3例であった. 長期予後の 観察期間は 0.8 から 15.1 年 (平均 9.3 年) で, 脳虚血発作と 脳出血発作を合わせた再発作について検討した。再出血発 作に関してはCTにて出血を確認した。脳血流検查は Single photon emission CT ${ }^{123}$ I-IMP SPECT) にて安静時 と acetazolamide負荷を術前後で施行した。手術は直接脑 血行再建術を施行した症例では全例両側に施行し, 出血側 より施行し初回手術より 4-8 週間後に対㲘手術を行い, 術 式は左右同じであった。手術施行例では術前後のもやもや 血管の変化を, 脳血管撮影もしくはMRA にて術 3 カ月以 上経過した時点で評価した。性差に関しては $\chi^{2}$ 乗検定に より，年齢と血行再建術施行時期は Kruscal-Wallis testに より比較検定した。経過観察中の再発作の頻度, もやもや 血管の変化を治療法に従って $\chi^{2}$ 乗検定で評価した。再発 作のなかった期間は Kaplan-Meier 法, ログランク検定に より解析し，再発作までの期間は Kruscal-Wallis testにて 検定した。

\section{結 果}

\section{1. 治療方針}

術前の脳血流検查 ${ }^{123} \mathrm{I}-\mathrm{IMP}$ SPECT) において 30 例全例 において安静時血流の低下と acetazolamide負荷に対する 反応性の低下が両側大脳半球で認められた。これょり脳血 行再建術を 30 例全例に勧めたが, 14 例 (47\%) は本人, 家 族の希望により保存的加療を行い，16例 (53\%) に対して 脑血行再建術を施行した. 脳血行再建術は出血発症 1 力月 以降の状態が安定した時期に施行した。手術手技は原則的 に直接血行再建術 (superficial temporal artery-middle cerebral artery (STA-MCA) anastomosis) としたが，術中 所見で適切な recipient arteryが脳表に存在していなかっ
た症例では間接血行再建術 (encephaloduroarteriosynangiosis, EDAS)を行った。結果として 10 例 (33\%) で直接血 行再建術，6例 (20\%) で間接血行再建術を施行した。直接 血行再建術施行群では両側とも STA-MCA anastomosisが 施行された。保存的加療施行群, 直接血行再建術施行群, 間接血行再建術施行群の 3 群間に年齢, 性差, 血行再建術 施行時期に有意差はなかった。保存的加療群においても経 過観察中に本疾患に対する薬物投与は行わなかった。

\section{2. 観察期間中の再発作}

最初の出血以降の経過観察中，再出血または脳虚血発作 が 12 例 (40\%) で生じ, 保存的加療群において 8 例, 直接 血行再建術施行群で 1 例, 間接血行再建術施行群で 3 例で あった．Kaplan-Meier 法による再発作が生じた率は，保 存的加療群で $6.67 \%$ /例/年, 直接血行再建術施行群で $1.53 \% /$ 例/年, 間接血行再建術施行群で $6.82 \% /$ 例/年であ り, 直接血行再建術施行群が他の治療法に比べて有意 $(\mathrm{p}<0.05)$ に低かった $($ Fig. 1)．また再発作が生じなかった 期間を比較すると, 保存的加療群で $2.71 \pm 2.39$ 年, 直接血 行再建術施行群で $9.3 \pm 0$ 年, 間接血行再建術施行群で $4.82 \pm 4.05$ 年であり, 直接血行再建術施行群では再発作出 現までの期間が有意 $(\mathrm{p}<0.05)$ に長期間で直接血行再建術 施行例の再発作に対する有用性が示された (Table 1).

再発作の内容は, 再出血 6 例, 脳虚血発作 6 例であった. 再出血は保存的加療群で 3 例直接血行再建術施行群で 1 例，間接血行再建術施行群で 2 例であった，再出血は全例 初回出血側と同側であった(Table 1).

\section{3. 術後もやもや血管の変化}

もやもや血管に対する脳血行再建術の効果は直接血行再 建術施行群に扔いてもやもや血管が $2 / 3$ 未満に減少したも

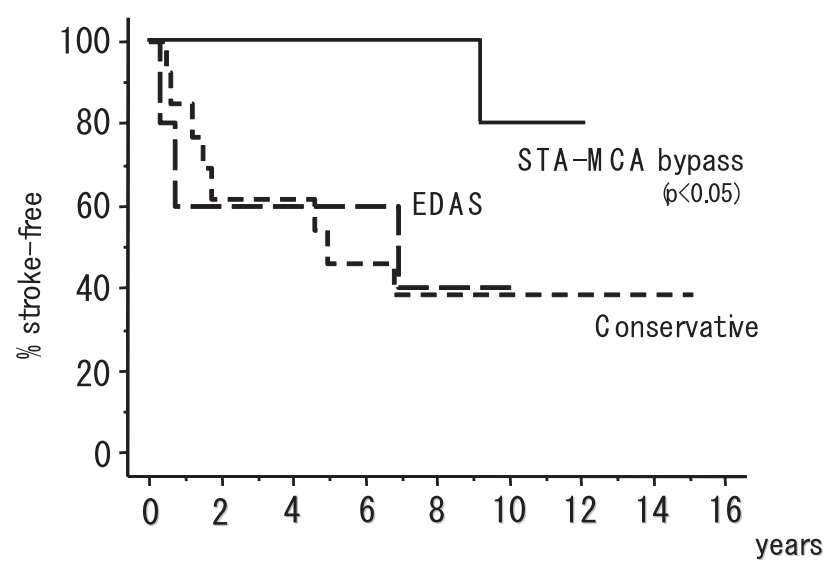

Fig. 1 Kaplan-Meier curves depicting the stroke-free interval after first bleed. The log-rank test was used to estimate differences among the treatments. 
Table 1 Incidence and characteristics of future stroke event of 30 hemorrhagic moyamoya disease subjected by treatment

\begin{tabular}{|c|c|c|c|}
\hline & Conservative & STA-MCA & EDAS \\
\hline Recurrent stroke rate $(\%)$ & $8(57 \%)$ & $1(10 \%)^{*}$ & $3(50 \%)$ \\
\hline$(\% /$ case $/$ year $)$ & 6.67 & $1.53 *$ & 6.82 \\
\hline Stroke free periods & $2.71 \pm 2.39$ & $9.3 *$ & $4.82 \pm 4.05$ \\
\hline \multicolumn{4}{|l|}{ Stroke type } \\
\hline Rebleeding & $3(21 \%)$ & $1(10 \%)$ & $2(33 \%)$ \\
\hline Ischemia & $5(36 \%)$ & 0 & $1(17 \%)$ \\
\hline \multicolumn{4}{|c|}{ Reduction of moyamoya vessels after operation } \\
\hline $1 / 3-2 / 3$ & & $7(70 \%)^{*}$ & $1(17 \%)$ \\
\hline$>2 / 3$ & - & $3(30 \%) *$ & $5(83 \%)$ \\
\hline
\end{tabular}

* There is statistically significant difference $(\mathrm{P}<0.05)$ among treatments.

Values are expressed as the means \pm standard deviation.

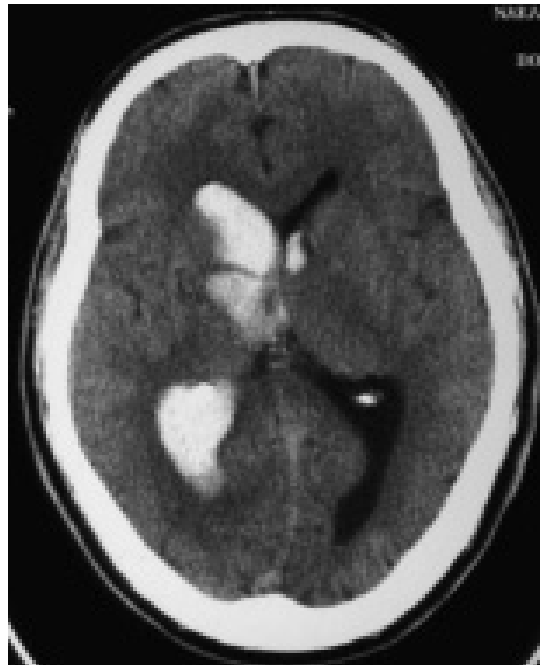

Fig. 2 An initial CT scan demonstrates small intracerebral hemorrhage with ventricular rupture.

のは 7 例， $2 / 3$ 以上であまり変化がなかったものは 3 例で あった。一方，間接血行再建術施行群では $2 / 3$ 未満に減少 したものが 1 例, $2 / 3$ 以上のものが 5 例あり, 直接血行再 建術施行群で有意 $(\mathrm{p}<0.05)$ にももや血管の減少が認め られた (Table 1).

\section{4. 代表症例}

50 歳男性. 突然の頭痛と歩行時のふらつきにて発症. CTにて脳室内出血を伴った右脳内出血を認め (Fig. 2), 脳血管撮影にてもやもや病と診断された (Fig. 3A，B). 入 院時意識清明, 明らかな麻瘏は認めなかった. 脳血流検査 $\left({ }^{123} \mathrm{I}\right.$-IMP SPECT) では両側前大脳動脈, 中大脳動脈領域 の血流低下が認められ，予備能も不良であった。 発症 2 力 月後に右直接血行再建術を, さらに 1 力月半後に左直接血
行再建術を施行した，術後神経症状の増悪を認めず，経過 良好であった。術後脳血管撮影において良好な直接血行再 建術部の開存ともやもや血管の縮小を認め (Fig. 3C, D), SPECTにおいても両側で脳血流の改善を認め, 3 年 6 力 月を経過した現在も神経症状の増悪なく経過良好である.

\section{考察}

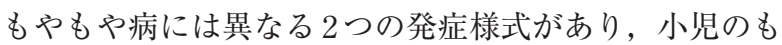
やもや病は虚血発作にて発症することが多いのに対して成 人もやもや病は出血で発症することが多い12)13)。虚血発 作に対する血行再建術はその有効性が示されており，特に 小児においてきわめて有効とされている ${ }^{3)}$. 一方出血発症 例に対しては近年，その治療法や長期予後について多くの 報告がなされているが，良好な結果を示すものばかりでは なくいまだ一定の見解が得られていないのが現状である1) 2) 4) 5)

出血発症もやもや病の再出血率は厚生省の報告によると 全体で $16.7 \%$ としている ${ }^{12)}$. 今回のわれわれの検討では 再発作は 12 例 (40\%) に認められ，そのうち再出血に関し ては 6 例 (20\%) に認められ，諸家の報告と差はないと考え られる。保存的加療群においては 8 例 (57\%) が再発作をき たし, 再出血は 3 例 (21\%) と保存的加療群での転帰が不良 であった. Morioka らは保存的加療による再出血率は 22 例 $(61 \%)$ とし，再出血後の転㷌は有意に不良であり， 46-55歳において再出血率が高いとしている ${ }^{11)}$.よって出 血発症もやもや病の再発作予防に対してなんらかの積極的 な対応が必要であると考えられる。

もやもや病における出血は大脳基底核, 脳室周囲深部白 質のもやもや血管が原因であろうと考えられており，その 機序としては慢性の脳血流不足により髄質深部である側脳 室上外側壁周辺部に小梗塞巣を形成し, その小梗塞巣から の梗塞性出血を生じる，または大脳基底核や脳室上衣下を 

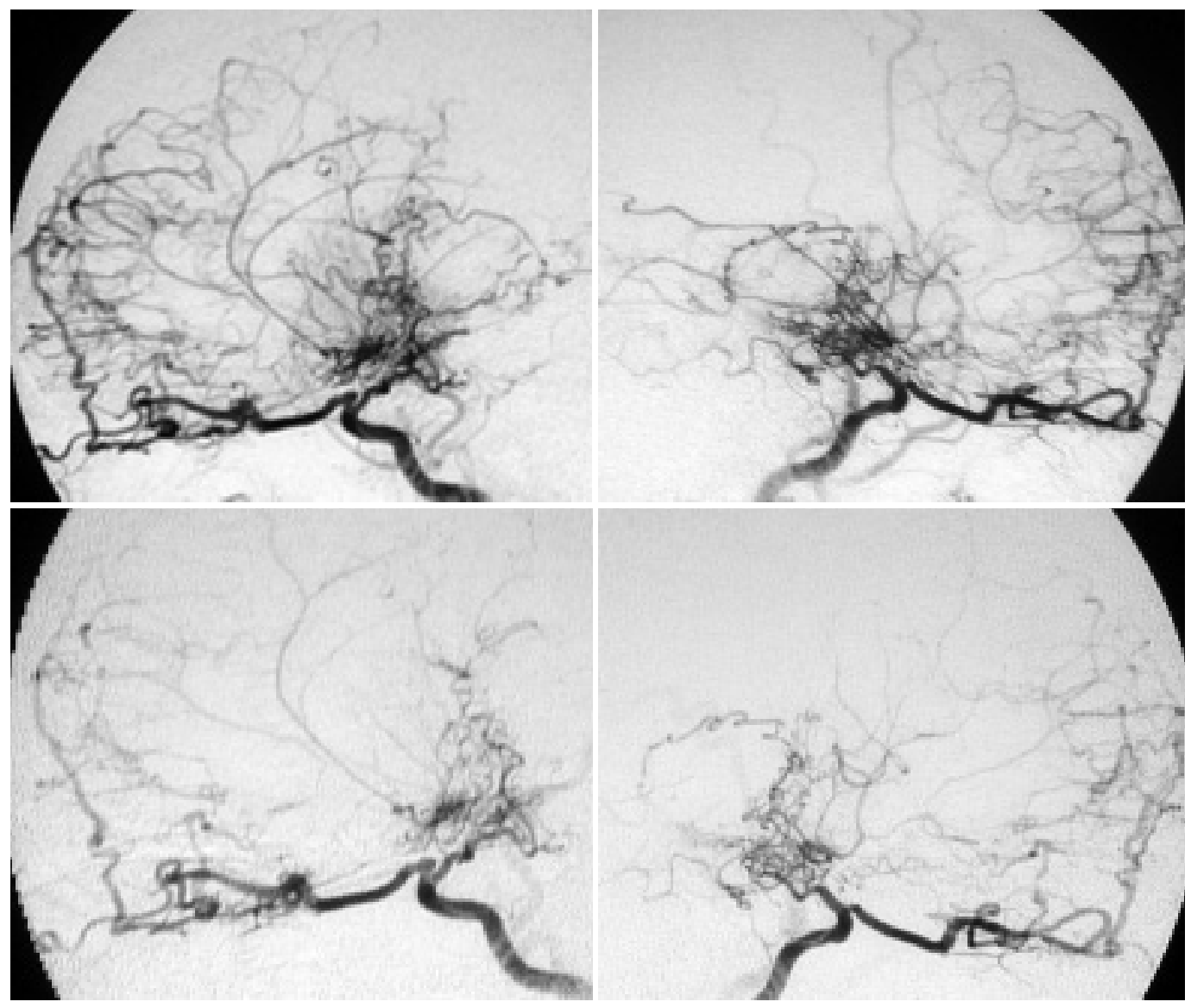

Fig. 3 Preoperative lateral views of left $(\mathrm{A})$ and right $(\mathrm{B})$ internal carotid angiography showing the moyamoya vessels in each side. Postoperative lateral views of left $(C)$ and right (D) internal carotid angiography depicting the reduction of moyamoya vessels in each side.

$\mathrm{A} \mid \mathrm{B}$

$\bar{C} \mid \mathrm{D}$
走行するもやもや血管にできた微小動脈瘤の破裂により基 底核出血や脳室内出血をもたらすと考えられている7).

近年 Morioka らは成人もやもや病患者において基底核 部周辺のもやもや血管を feedingする前脈絡叢動脈の拡張 や異常な分枝が出血発症に有意に相関し，これらの存在か ら出血を予測することができると報告している ${ }^{10)}$ 。した がって再出血を予防するにはこれらもやもや血管への血行 力学的負荷を軽減し, さらにはもやもや血管の減少・消退 をもたらすような治療を選択する必要があると考えられ る. 今回のわれわれの結果では, 保存的加療群における再 出血が 8 例 (57\%) であるのに対し直接血行再建術後の再出 血は 1 例 (10\%)であり，また発症から再出血までの期間は 直接血行再建術群で 9.3 年と保存的加療群 ( $2.71 \pm 2.39$ 年) に比べ有意に良好であり, やはり出血発症もやもや病にお いて直接血行再建術が再出血を予防しうることが示され た。

血行再建術によってもやもや血管が減少することは知ら れているが，特に小児例では血行再建術によってほとんど
の症例でもやもや血管の減少がみられ，血行再建術後の出 血発作がほとんどみられないことを考慮するともやもや血 管の減少は成人出血発症もやもや病においても再出血率を 低下させる可能性が強く示唆されると考えられる。一般に 血行再建術には直接血行再建術と間接血行再建術がある が，成人例においては間接血行再建術のみでは十分な側副 血行が得られないことがあり，直接血行再建術が勧められ ている。黑田らの検討によると, 間接的血行再建術施行群 では再出血のリスクが直接血行再建術と間接的血行再建術 の併用群に比し約 6 倍であり両群間では脳による側副血行 路の形成に明らかな差が認められ，もやもや血管の消退や 消失の差と関連していた ${ }^{8)}$. 今回のわれわれの検討におい ても直接血行再建術施行群に対する再発作のリスクは間接 血行再建術施行群においては 5 倍，保存的加療群において は約 6 倍であった。 また血行再建術後のもやもや血管の減 少は直接血行再建術群では 7 例 $(70 \%)$ に認められたのに対 し，間接血行再建術群では 1 例 (17\%) と有意な差が認めら れた。したがって出血発症もやもや病患者において直接血 
行再建術が間接血行再建術より有意に再発作を予防し，血 行再建術後のもやもや血管の変化が再出血の予防に関与し ていることが示唆された。しかし前回の検討 ${ }^{6)}$ と同様間接 血行再建術の成績が悪く, これには術中所見で適切な recipient arteryが脳表に存在していなかった症例では間 接血行再建術 (EDAS) を行うという症例選択の方法にバイ アスがかかっていることは否めない.つまり間接血行再建 術群の症例は直接血行再建術群よりも病期が進行してお り, そのために術後のもやもや血管の減少もあまり認めら れないという可能性も考えられる. よって今回の検討で一 概に間接血行再建術が出血発症もやもや病の治療に無効で あると結論することはできないが，このような症例の治療 に際してはさらなる検討と工夫が必要であると考えられ る.

今回のわれわれの検討では出血発症のもやもや病患者に おいて直接血行再建術は脳出血または脳虚血などの再発作 に対して予防効果があることが示されたが，直接脳血行再 建術の効果を近年重要視されているエビデンスに基づいた データとして客観的に示すことは, 症例が少ない本疾患に おいてはこれまで困難であり, 全国規模での randomized controlled trial (RCT) が不可欠である. 以上の経緯から， 厚生労働省の「ウイリス動脈輪閉塞症の病因・病態に関す る研究班」では, 2001 年 1 月から脳血行再建術が出血発 症成人もやもや病の再出血を予防し転帰を改善しうるかど うかを検討するために, 多施設による前向き無作為臨床試 験(Japan Adult Moyamoya $\langle\mathrm{JAM}\rangle$ Trial)を開始しており, その結果が期待される。

\section{結論}

出血発症のもやもや病患者において直接血行再建術は脳 出血または脳虚血などの再発作に対して予防効果があるこ とが示された。

\section{文献}

1) Aoki N: Cerebrovascular bypass surgery for the treat- ment of moyamoya disease: unsatisfactory outcome in the patients presenting with intracranial hemorrhage. Surg Neurol 40: 372-377, 1993

2) Houkin K, Kamiyama H, Abe H, et al: Surgical therapy for adult moyamoya disease. Can surgical revascularization prevent the recurrence of intracranial hemorrhage? Stroke 27: 1342-1346, 1996

3) Karasawa J, Houho H, Ohnishi $\mathrm{H}$, et al: Long-term followup study after extracranial-intracranial bypass surgery for anterior circulation ischemia in childhood moyamoya disease. J Neurosurg 77: 84-89, 1982

4) Kawaguchi S, Sakaki T, Kakizaki T, et al: Clinical features of the haemorrhage type moyamoya disease based on 31 cases. Acta Neurochir (Wien) 138: 1200-1210, 1996

5) Kawaguchi S, Okuno S, Sakaki T: Effect of direct arterial bypass on the prevention of future stroke in patients with the hemorrhagic variety of moyamoya disease. $J$ Neurosurg 93: 397-401, 2000

6）川口正一郎, 榊 寿右, 浦西龍之介, ほか：もやもや病出 血例の長期的予後一直接血行再建術の有用性について一. 脳卒中の外科 30: 120-124, 2002

7) Kobayashi E, Saeki N, Oishi H, et al: Long-term history of hemorrhagic moyamoya disease in 42 patients. $J$ Neurosurg 93: 976-980, 2000

8）黑田 敏，宝金清博，石川達哉，ほか：小児および成人も やもや病に対する脳血行再建術の長期効果. 脳卒中の外科 30: 369-374, 2002

9) Mizoi K, Kayama T, Yoshimoto T, et al: Indirect revascularization for moyamoya disease: is there a beneficial effect for adult patients? Surg Neurol 45: 541-549, 1996

10) Morioka M, Hamada J, Kawano $T$, et al: Angiographic dilatation and branch extension of the anterior choroidal and posterior communicating arteries are predictors of hemorrhage in adult moyamoya patients. Stroke 34: 90-95, 2003

11) Morioka M, Hamada J, Tokuda T, et al: High-risk age for rebleeding in patients with hemorrhagic moyamoya disease: long-term follow-up study. Neurosurg 52: 1049-1055, 2003

12) Suzuki J, Takaku A: Cerebral vascular "moyamoya" disease. A disease showing abnormal net-like vessels in base of brain. Arch Neurol 20: 288-299, 1969

13) Yoshida $Y$, Yoshimoto $T$, Shirane R, et al: Clinical course, surgical management, and long-term outcome of moyamoya patients with rebleeding after an episode of intracerebral hemorrhage. An extensive follow-up study. Stroke 30: 2272-2276, 1999 